\title{
Kekuatan Pembuktian Fotokopi Surat yang Tidak Dapat Dicocokkan dengan Aslinya dalam Perkara Perdata
}

\author{
Devina Puspita Sari \\ Program Magister Ilmu Hukum Universitas Indonesia \\ devinapuspita15@gmail.com
}

\section{Abstract}

The photocopy acceptable in the court if it matched with the original letter and the strength of that photocopy is the same as the original letter. However, sometimes the original letter has been lost so that it cannot be shown at trial. This paper discusses whether a photocopy that cannot be matched with the original letter can be accepted in the civil procedural law and if it can be accepted how the strength of it, then the discussion will look at the judge's consideration in two cases related to the issue. The results of discussions are that photocopies that cannot be matched with the original letter can be accepted as evidence if the photocopy matches or is strengthened with other evidence, as the jurisprudence of Decision Nr. 112 K/Pdt/ 1996 and Decision Nr. 410 K/pdt/2004. The jurisprudence has been followed by similar cases, which is the Decision of the Central Jakarta District Court Nr. 164/Pdt.G/2004/PN.Jkt.Pst jo. Decision of The Jakarta High Court Nr. 234/Pdt/2005/PT.DKI jo. Decision of The Supreme Court Nr. $1498 \mathrm{~K} / \mathrm{Pdt} / 2006$ which in this case a photocopy can be accepted because it is strengthened by the recognition of the opposing party and The Pontianak District Court Nr.52/Pdt.G/2003/PN.Ptk which received a photocopy because it was strengthened with witness testimony. The photocopy has a free power of proof (depends on the judge's assessment). The use and assessment of the strength of the photocopy cannot be independent, but must be linked to other valid evidence.

Keywords: photocopy; the strength of evidentiary; civil cases. 


\section{Abstrak}

Fotokopi surat dapat diterima dalam persidangan apabila dapat dicocokkan dengan aslinya, dan kekuatan pembuktiannya sama seperti surat aslinya. Tulisan ini membahas, dalam hal surat aslinya tidak dapat ditunjukkan di persidangan, apakah fotokopi surat dapat diterima dalam pembuktian hukum acara perdata, dan, apabila dapat diterima, bagaimanakah kekuatan pembuktiannya. Artikel ini menunjukkan, fotokopi surat yang tidak dapat dicocokkan dengan aslinya dapat diterima sebagai alat bukti surat jika bersesuaian atau dikuatkan dengan alat bukti lain, sebagaimana Putusan Mahkamah Agung Nomor 112 K/Pdt/ 1996 dan Putusan Nomor 410 K/ pdt/2004 yang telah menjadi yurisprudensi. Yurisprudensi ini telah diikuti dalam perkara serupa, yaitu dalam Putusan Pengadilan Negeri Jakarta Pusat Nomor 164/Pdt.G/2004/ PN.Jkt.Pst jo. Putusan Pengadilan Tinggi Jakarta Nomor 234/Pdt/2005/PT.DKI jo. Putusan Mahkamah Agung Nomor $1498 \mathrm{~K} / \mathrm{Pdt} / 2006$, di mana dalam perkara ini fotokopi surat dapat diterima karena dikuatkan dengan pengakuan pihak lawan. Demikian juga dalam Putusan Pengadilan Negeri Pontianak Nomor 52/Pdt.G/2003/PN.Ptk, yang menerima fotokopi surat yang tidak dapat dicocokkan dengan aslinya karena dikuatkan dengan alat bukti keterangan saksi. Dengan demikian, fotokopi surat memiliki kekuatan pembuktian yang bebas, artinya diserahkan kepada penilaian hakim. Penggunaan dan penilaian kekuatan pembuktian fotokopi tersebut tidak dapat berdiri sendiri, tetapi harus dikaitkan dengan alat bukti lainnya yang sah.

Kata kunci: fotokopi; kekuatan pembuktian; perkara perdata.

\section{A. Pendahuluan}

Artikel ini membahas kekuatan pembuktian fotokopi surat yang tidak dapat dicocokkan dengan aslinya dalam perkara perdata. Pembahasan ini menjadi perlu karena dalam suatu pembuktian di pengadilan, bisa jadi surat asli tidak dapat ditunjukkan oleh pihakpihak yang berperkara, sehingga hanya bisa diajukan fotokopinya. Dalam membahas persoalan tersebut, artikel ini mendasarkan pada dua putusan pengadilan yang dalam pemeriksaan perkaranya terdapat fotokopi surat yang tidak dapat dicocokkan dengan aslinya, yaitu Putusan Pengadilan Negeri Jakarta Pusat Nomor 164/Pdt.G/2004/ 
PN.Jkt.Pst jo. Putusan Pengadilan Tinggi Jakarta Nomor 234/ Pdt/2005/PT.DKI jo. Putusan Mahkamah Agung Nomor 1498 K/ Pdt/2006 dan Putusan Pengadilan Negeri Pontianak Nomor 52/ Pdt.G/2003/PN.Ptk.

Pembuktian sendiri dalam suatu persidangan merupakan upaya para pihak yang berperkara dalam rangka meyakinkan hakim atas kebenaran peristiwa atau kejadian yang diajukan oleh para pihak dengan menggunakan alat-alat bukti yang ditetapkan oleh undangundang. ${ }^{1}$ Dalam hukum acara perdata, alat bukti yang dikenal secara sah adalah alat bukti tertulis atau surat, alat bukti saksi, persangkaan, pengakuan dan sumpah, sebagaimana diatur dalam Pasal $164 \mathrm{HIR},{ }^{2}$ atau Pasal 284 Rbg. ${ }^{3}$ atau Pasal 1866 KUHPerdata. ${ }^{4}$ Berdasarkan alat-alat bukti yang diajukan tersebut maka majelis hakim yang memeriksa perkara melakukan penilaian terhadap pembuktian yang dilakukan oleh para pihak.

Dengan menganut sistem pembuktian positif (positief wettelijke) $)^{5}$ pada hukum acara perdata di Indonesia, ${ }^{6}$ yang mendasarkan penilaian

1 Pengadilan Tinggi Agama Makassar, Buku Pedoman Kerja Hakim, Panitera dan Jurusita Sewilayah Pengadilan Tinggi Agama Makassar (Makassar: tanpa penerbit, edisi revisi, 2011), hlm. 34 .

2 Het Herziene Indonesisch Reglement (HIR atau Reglemen Indonesia yang diperbaharui: S.1848 No. 16, S. 1941 No. 44), Psl. 164.

3 Rechtsreglement Buitengewesten (Rbg. atau Reglemen daerah seberang: S. 1927 No. 227), Psl. 284.

4 Kitab Undang-Undang Hukum Perdata (Burgerlijk Wetboek), terj. R. Subekti dan R. Tjitrosudibio, (Jakarta: Pradnya Paramita, 2004), Psl. 1866.

5 Menurut Simons, sistem atau teori pembuktian berdasarkan undangundang secara positif atau positief wettelijke berusaha meminimalisasi semua pertimbangan subyektif hakim serta mengikat hakim berdasarkan aturan pembuktian. Andi Hamzah, Pengantar Hukum Acara Pidana di Indonesia (Jakarta: Ghalia Indonesia, 1984), hlm. 229.

6 Kebenaran yang dicari dalam perkara perdata di Indonesia adalah kebenaran formil, artinya hakim tidak dapat melebihi batas yang diajukan para pihak dalam suatu perkara. Kebenaran formil merupakan sistem pembuktian positif atau positief wettelijke. Djamanat Samosir, Hukum Acara Perdata: Tahap-Tahap Penyelesaian Perkara Perdata (Bandung: Nuansa Aulia, 2011), hlm. 212. Hukum acara perdata di Indonesia menganut sistem pembuktian positif atau positief wettelijke. Hakim terikat dengan alat-alat bukti yang sah (yang ditentukan oleh undang-undang) dan hanya dapat memutus berdasarkan alat-alat bukti tersebut. Hal ini dapat dilihat pada HIR, Pasal 
alat bukti berdasarkan alat bukti yang telah ditetapkan oleh undangundang secara positif (tanpa diperlukan adanya keyakinan hakim), menjadikan alat bukti surat sebagai alat bukti yang sangat penting untuk diajukan oleh para pihak yang berperkara. ${ }^{7}$ Alat bukti surat terdiri dari surat bukan akta dan surat akta. Surat akta terbagi lagi menjadi akta otentik dan akta di bawah tangan. Akta otentik merupakan surat yang dibuat oleh atau di hadapan pejabat umum yang berwenang ${ }^{8}$ untuk memberikan bukti yang cukup bagi para pihak serta ahli warisnya termasuk setiap orang yang mendapatkan hak dari padanya, sedangkan akta-akta lainnya, yang bukan merupakan akta otentik, disebut akta di bawah tangan. ${ }^{9}$

Dalam kaitannya dengan alat bukti surat, baik yang berupa surat akta maupun surat bukan akta, penting untuk dibahas bagaimana

138 ayat (2), Pasal 150 ayat (3), Pasal 154 ayat (1), 155 ayat (1), dan 156 ayat (1), serta merujuk pada Putusan Mahkamah Agung RI No. 290K/Sip/ 1973 tanggal 3 Agustus 1974. Dikutip dari Winotia Ratna, "Perbandingan Alat Bukti Keterangan Saksi pada Hukum Acara Perdata dalam Sistem Hukum Indonesia dengan Singapura: Studi Kasus Beckket Pte. Ltd. Melawan Deutcshe Bank Ag.”, (skripsi, Universitas Indonesia, Depok, 2008), hlm. 36.

7 Surat adalah sekumpulan tanda baca yang jika dirangkaikan atau saling dihubungkan mengandung maksud atau arti tertentu. Soetomo Ramelan, "Peranan Surat dalam Hukum Pembuktian", Jurnal Hukum dan Pembangunan, 17, 1 (1987), hlm. 7. Lihat juga Muhammad Nasir, yang berpendapat surat atau alat bukti tertulis sebagai segala sesuatu yang terdapat tandatanda bacaan dengan maksud mencurahkan pikiran dan isi hati seseorang yang ditujukan kepada dirinya dan/atau orang lain serta dapat digunakan sebagai alat pembuktian. Muhammad Nasir, Hukum Acara Perdata (Jakarta: Djambatan, cetakan kedua, 2005), hlm. 150.

8 Salah satu pegawai umum yang diberi wewenang oleh undang-undang untuk membuat akta otentik adalah Notaris berdasarkan UU No. 30 Tahun 2004 tentang Jabatan Notaris. Menurut Pasal 1 butir (7) UU No. 30 Tahun 2004, akta notaris merupakan akta otentik yang dibuat oleh atau dihadapan notaris dengan bentuk dan tata cara yang diatur dalam UU Jabatan Notaris, sedangkan minuta akta adalah asli dari akta notaris (Pasal 1 butir (8) UU No. 30 Tahun 2004). Salinan akta merupakan salinan kata per kata dari seluruh akta yang tercantum frasa "diberikan sebagai salinan yang sama bunyinya" pada bagian bawah salinan akta (Pasal 1 butir (9) UU N0. 30 Tahun 2004). Indonesia, Undang-Undang Jabatan Notaris, UU No. 30 Tahun 2004, L.N. No. 117 Tahun 2004, T.L.N. No. 4432, Psl. 1 butir (7), (8), dan (9).

9 R. Subekti, Hukum Pembuktian (Jakarta: Pradnya Paramita, cetakan ketujuh belas, 2008), hlm. 26. 
jika surat tersebut yang asli tidak ada, sehingga yang diajukan dalam persidangan hanyalah fotokopinya. Menurut M. Yahya Harahap, salinan, yang merupakan turunan dari suatu surat, hanya dapat dipercaya apabila sesuai dengan surat aslinya dan cara menguji adalah dengan menunjukkan aslinya. Jika salinan tersebut sesuai dengan aslinya maka nilai kekuatan pembuktiannya sama dengan kekuatan pembuktian surat aslinya, yaitu berkekuatan sebagai pembuktian yang sempurna dan mengikat. Suatu salinan hanya menjadi permulaan pembuktian tulisan jika berupa turunan atau salinan akta otentik yang dibuat menurut minutnya bukan dikeluarkan notaris yang membuatnya, atau salinan sah dari salinan sah (Pasal 1889 ke-4 KUHPerdata, Pasal 302 ke-4 Rbg), atau salinan yang telah disangkal, atau salinan yang tidak diakui atau dibantah pihak lawan. Agar salinan yang hanya berupa permulaan pembuktian tulisan tersebut menjadi sempurna dan mengikat, salinan tersebut harus disesuaikan dengan aslinya atau sekiranya aslinya tidak ada lagi cara untuk membuktikan persamaan itu dapat dilakukan dengan bantuan alat bukti lain yaitu surat, saksi dan ahli. ${ }^{10}$

Suatu salinan surat hampir sama dengan fotokopi. ${ }^{11}$ Menurut M. Yahya Harahap, jika dibandingkan dengan salinan, fotokopi hampir tidak ada bedanya. Namun, hukum pembuktian memberikan penilaian dan penghargaan kepada salinan jauh lebih tinggi daripada fotokopi, yang dapat dilihat dalam Pasal 1889 KUHPerdata dan Pasal 302 Rbg. Sedangkan pada fotokopi, belum ada ketentuan yang mengakomodasi penilaiannya. Pada umumnya, keabsahan identiknya fotokopi dengan aslinya diakui apabila para pihak dapat menunjukkan surat aslinya. ${ }^{12}$ Sudikno Mertokusumo, dengan

10 M. Yahya Harahap, Hukum Acara Perdata tentang Gugatan, Persidangan, Penyitaan, Pembuktian, dan Putusan Pengadilan (Jakarta: Sinar Grafika, 2004), hlm. 616-619.

11 Kamus Besar Bahasa Indonesia mendefinisikan fotokopi sebagai "hasil reproduksi (penggandaan) fotografis terhadap barang cetakan (tulisan)" (https://kbbi.web.id/fotokopi, diakses 12/11/2019), sedangkan salinan adalah "suatu turunan surat" (https://kbbi.web.id/salinan, diakses $12 / 11 / 2019)$.

12 Harahap, Hukum Acara Perdata tentang Gugatan, hlm. 622. 
mendasarkan pada Putusan Mahkamah Agung Nomor $701 \mathrm{~K} /$ Sip/1974, mengemukakan penerimaan fotokopi sebagai alat bukti jika disertai "keterangan atau dengan cara apapun secara sah ternyata bahwa fotokopi-fotokopi tersebut sesuai dengan aslinya". ${ }^{13}$ Putusan Mahkamah Agung Nomor 112 K/Pdt/ 1996 tanggal 17/9/1998 juga menetapkan hal yang sama, bahwa fotokopi surat sebagai "alat bukti surat" yang tidak disertai atau dicocokkan dengan aslinya atau tanpa didukung oleh keterangan saksi dan/atau alat bukti lainnya, maka bukan termasuk alat bukti yang sah. ${ }^{14}$

Dalam artikel ini, kekuatan pembuktian fotokopi surat yang tidak dapat dicocokkan dengan aslinya akan ditelaah berdasarkan putusan pengadilan yang dalam pembuktiannya terdapat fotokopi surat yang tidak dapat dicocokkan dengan aslinya. Putusan pengadilan yang menjadi bahan penulisan artikel ini adalah Putusan Pengadilan Negeri Jakarta Pusat Nomor 164/Pdt.G/2004/PN.Jkt.Pst jo. Putusan Pengadilan Nomor 234/Pdt/2005/PT.DKI jo. Putusan Mahkamah Agung Nomor $1498 \mathrm{~K} / \mathrm{Pdt} / 2006$ dan Putusan Pengadilan Negeri Pontianak Nomor 52/Pdt.G/2003/PN.Ptk.

Dalam membahas kekuatan pembuktian fotokopi surat yang tidak dapat dicocokkan dengan aslinya, artikel ini setelah ini akan menguraikan alat bukti tertulis dan kekuatan pembuktiannya dalam perkara perdata. Uraian ini dimaksudkan untuk memperjelas terlebih dahulu bagaimana pembuktian dilakukan dan siapa pula pihak yang melakukannya. Pada sub-bahasan ini diuraikan juga alat bukti tertulis dan kekuatan pembuktiannya. Fotokopi surat dalam hal ini merupakan bagian dari yang tertulis namun hanya merupakan salinan. Pada bagian selanjutnya, dengan menggunakan bahan putusan pengadilan, dibahas bagaimana hakim memperlakukan fotokopi surat yang tidak dapat dicocokkan dengan aslinya.

13 Sudikno Mertokusumo, Hukum Acara Perdata Indonesia (Yogyakarta: Liberty, edisi ketujuh, 2006), hlm. 165.

14 M. Ali Boediarto, Kompilasi Kaidah Hukum Putusan Mahkamah Agung Hukum Acara Perdata Masa Setengah Abad (Jakarta: Swara Justisia, 2005), hlm. 149152. 


\section{B. Alat Bukti Surat dan Kekuatan Pembuktiannya dalam Perkara Perdata}

Pembuktian merupakan upaya para pihak yang berperkara dalam rangka meyakinkan hakim atas kebenaran suatu peristiwa atau kejadian yang dikemukakan oleh para pihak dengan menggunakan alat-alat bukti yang telah ditetapkan (secara limitatif) oleh undangundang. ${ }^{15}$ Ini berarti, pembuktian itu bertujuan untuk memberi kepastian kepada hakim akan kebenaran peristiwa konkrit yang disengketakan. ${ }^{16}$

Penilaian pembuktian adalah suatu penilaian yang dilakukan oleh hakim terhadap bukti-bukti yang dimajukan oleh pihak sesuai dengan kenyataannya. Hakim karena undang-undang terikat secara positif kepada alat bukti tertentu sehingga hakim tidak bebas menilainya, tetapi hakim diberi kebebasan untuk menilai pembuktian. Oleh karena itu penilaian pembuktian adalah penilaian sesuai dengan kenyataan. Terdapat tiga teori mengenai keterikatan hakim dalam menilai pembuktian, yaitu ${ }^{17}$ pertama, teori pembuktian bebas. Teori ini tidak menginginkan adanya ketentuan atau aturan yang mengikat hakim, sehingga hakim bebas dalam memberikan penilaian atas pembuktian. Kedua, teori pembuktian negatif. Teori ini menginginkan adanya aturan atau ketentuan yang mengikat. Ketentuan ini harus memberikan batasan-batasan kepada hakim untuk melakukan sesuatu yang berhubungan dengan pembuktian, sehingga hakim dilarang dengan pengecualian (Pasal 169 HIR, Pasal 306 Rbg., atau Pasal 1905 KUHPerdata). Ketiga, teori pembuktian positif. Teori ini menginginkan adanya perintah kepada hakim. Hakim diberikan suatu kewajibkan, tetapi dengan syarat (Pasal 165 HIR, Pasal 285 Rbg., Pasal 1870 KUHPerdata).

15 Pengadilan Tinggi Agama Makassar, Buku Pedoman Kerja Hakim, Panitera dan Jurusita Se Wilayah Pengadilan Tinggi Agama Makassar (Makassar: tanpa penerbit, edisi revisi, 2011), hlm. 34.

16 Elisabeth Nurhaini Butarbutar, "Arti Pentingnya Pembuktian dalam Proses Penemuan Hukum di Peradilan Perdata”, Mimbar Hukum, 22, 2 (2010), hlm. 351.

17 Mertokusumo, Hukum Acara Perdata Indonesia, hlm. 141. 
Sistem pembuktian yang dianut dalam sistem hukum acara perdata di Indonesia adalah sistem pembuktian positif (positief wettelijke), yang mendasarkan penilaian alat bukti berdasarkan alat bukti yang telah ditetapkan undang-undang secara positif (tanpa diperlukan adanya keyakinan hakim). Alat-alat bukti yang sah (yang ditentukan oleh undang-undang) mengikat hakim dan hanya berdasarkan alat-alat bukti tersebut hakim dapat memutus. Hal ini dapat dilihat pada HIR, Pasal 138 ayat (2), Pasal 150 ayat (3), Pasal 154 ayat (1), 155 ayat (1), dan 156 ayat (1). ${ }^{18}$ Kebenaran yang dicari dalam perkara perdata adalah kebenaran formil, dalam arti hakim tidak boleh melebihi batas yang diajukan para pihak yang berperkara. ${ }^{19}$

Pasal 163 HIR, ${ }^{20}$ Pasal 283 Rbg., ${ }^{21}$ atau Pasal 1865 KUHPerdata ${ }^{22}$

18 Ratna, "Perbandingan Alat Bukti Keterangan Saksi”, hlm. 36.

19 Samosir, Hukum Acara Perdata, hlm. 212.

20 Pasal 164 HIR: "barang siapa, yang mengatakan ia mempunyai hak, atau ia menyebutkan suatu perbuatan untuk menguatkan haknya itu, atau untuk membantah hak orang lain, maka orang itu harus membuktikan adanya hak itu atau adanya kejadian itu”.

21 Pasal 283 Rbg.: "barangsiapa beranggapan mempunyai suatu hak atau suatu keadaan untuk menguatkan haknya atau menyangkal hak seseorang lain, harus membuktikan hak atau keadaan itu”.

22 Pasal 1865 KUHPerdata: "Setiap orang yang mendalilkan bahwa ia mempunyai sesuatu hak, atau, guna meneguhkan haknya sendiri maupun membantah suatu hakoranglain, menunjukpada suatu peristiwa, diwajibkan membuktikan adanya hak atau peristiwa tersebut". Kitab Undang-Undang Hukum Perdata [Burgerlijk Wetboek], Ps. 1865. Di samping pedoman umum yang diatur dalam Pasal 1865 KUHPerdata, terdapat ketentuan khusus yang secara tegas mengatur mengenai beban pembuktian. Ketentuan tersebut antara lain: 1) itikad baik tidak perlu dibuktikan oleh seseorang yang menguasai barang, namun orang yang menyatakan adanya itikad buruk harus membuktikannya (Pasal 533 KUHPerdata), 2) seseorang yang telah memulai menguasai sesuatu barang untuk orang lain, akan dianggap meneruskan penguasaan itu, kecuali apabila terbukti sebaliknya (Pasal 535 KUHPerdata),3)Debituryangharusmembuktikanadanyakeadaanmemaksa (Pasal 1244 KUHPerdata), 4) pihak yang menuntut ganti rugi berdasarkan perbuatan melanggar hukum, harus membuktikan adanya unsur kesalahan (Pasal 1365 KUHPerdata), 5) apabila debitur dapat menunukan tiga kwitansi terakhir yang berturut-turut tanggal pembayarannya, ia dibebaskan untuk membuktikan pembayaran-pembayaran sebelum tiga kwitansi tersebut (Pasal 1394 KUHPerdata), 6) jika terdapat bukti pembayaran pokok uang pinjaman dianggap membuktikan telah terbayarnya bunga dan pinjaman tersebut (Pasal 1769 KUHPerdata), 7) seseorang dianggap pemilik terhadap 
telah menentukan pihak mana yang memiliki beban pembuktian dalam hukum acara perdata. Ketentuan tersebut memberikan beban pembuktian kepada setiap pihak yang mengemukakan dalil di persidangan. Apabila para pihak mendalilkan bahwa ia memiliki hak tertentu atau menjelaskan perbuatan tertentu, maka pihak tersebut wajib membuktikan dalilnya dan sebaliknya bagi yang membantah atau menyangkal dalil pihak lain, ia wajib membuktikan bantahannya atau sangkalannya tersebut.

Sebagaimana telah disebutkan sebelumnya, alat bukti yang dikenal secara sah dalam undang-undang terkait hukum acara perdata, yaitu alat bukti tertulis atau surat, alat bukti saksi, persangkaan, pengakuan dan sumpah (Pasal $164 \mathrm{HIR} /$ Pasal 284 Rbg./Pasal 1866 KUHPerdata). Ketentuan mengenai alat bukti tertulis atau surat diatur dalam Pasal 138, 165, 167 HIR, Pasal 164, 285, 305 Rbg., atau Pasal 1867-1894 KUHPerdata. Alat bukti tertulis atau surat dibagi menjadi dua macam, yaitu akta dan bukan akta. Termasuk akta yaitu dapat berupa akta otentik, yaitu akta yang dibuat oleh pejabat (acta ambtelijk, prosese verbal acte) atau akta yang dibuat dihadapan pejabat (partij acte), serta akta di bawah tangan. Pengertian akta otentik adalah surat yang dibuat oleh atau dihadapan pejabat umum yang berwenang dalam rangka memberikan bukti yang cukup bagi kedua

barang bergerak yang ia kuasai (Pasal 1977 ayat (1) KUHPerdata), 8) seorang suami dapat menyangkal seorang anak (sebagai anaknya yang sah) yang lahir dari istrinya, jika ia dapat membuktikan bahwa dalam kurun waktu antara 300 hari dan 180 hari sebelum anak itu lahir, ia tidak melakukan hubungan badan dengan istrinya (Pasal 252 KUHPerdata), 9) seseorang yang mengemukakan bahwa ia mendapatkan suatu hak dari orang yang tidak jelas tempat tinggalnya dan tidak pasti apakah orang tersebut masih hidup, maka harus dibuktikan, bahwa orang yang tidak jelas tempat tinggalnya tersebut masih hidup pada saat hak yang dimaksudkan, memang merupakan hak yang melekat pada orang tersebut (Pasal 489 KUHPerdata), 10) pihak pengangkut barang harus mengganti kerugian yang diderita pemilik barang, apabila barang yang diangkut tidak sama sekali atau hanya sebagian yang diserahkan kepada pemilik itu, kecuali apabila pengangkut tersebut dapat membuktikan bahwa tidak dapat diserahkannya barang tersebut merupakan akibat suatu peristiwa diluar kemampuan manusia (Pasal 468 ayat (2) KUHD), ketentuan khusus mengenai beban pembuktian ini dikutip dari Teguh Samudera, Hukum Pembuktian dalam Acara Perdata (Bandung: PT. Alumni, cetakan kedua, 2004), hlm. 24-26. 
pihak, ahli warisnya serta setiap orang yang mendapatkan hak dari akta tersebut, tentang segala hal yang termuat dalam surat tersebut serta hal yang hanya bersifat pemberitahuan saja (namun hanya jika yang diberitahukan berhubungan langsung dengan perihal yang ada pada akta tersebut (Pasal 165 HIR, 285 Rbg, 1868 KUHPerdata).

Akta yang dibuat oleh pejabat adalah akta yang dibuat oleh pejabat berwenang yang menerangkan apa yang dilihat, didengar, dan dilakukannya. Misalnya berita acara yang dibuat oleh polisi, akta catatan sipil, dan sebagainya. Adapun akta yang dibuat oleh para pihak di hadapan pejabat yang berwenang apabila pejabat menerangkan apa yang dilihat, didengar, dan dilakukannya dan para pihak mengakui keterangan akta tersebut dengan menandatanganinya. Contohnya, akta jual beli PPAT, akta pendirian Perseroan Terbatas, dan lainlain. ${ }^{23}$

Akta dibawah tangan tidak ada aturannya dalam HIR, pengaturan akta di bawah tangan terdapat dalam dalam Lembaran Negara 1867 No. 29, sedangkan untuk daerah luar Jawa dan Madura diatur dalam Pasal 286-305 Rbg., selain itu diatur pula dalam Pasal 1876-1894 KUHPerdata. ${ }^{24}$ Akta di bawah tangan merupakan akta yang dibuat sendiri oleh para pihak tanpa bantuan pejabat umum dengan maksud akan dijadikan sebagai alat pembuktian. Akta di bawah tangan akan memberikan pembuktian yang cukup apabila ada pengakuan yang menyatakan bahwa benar dibuat dan ditandatangani oleh pihak yang bersangkutan (Pasal 288 Rbg., Pasal 1875 KUHPerdata). Dalam Pasal 1881 KUHPerdata/ Pasal 294 Rbg., dan Pasal 1883 KUHPerdata/ Pasal 297 Rbg., diatur mengenai surat-surat di bawah tangan yang bukan merupakan akta, yaitu buku daftar (register), surat-surat rumah tangga dan catatan-catatan yang diberikan oleh kreditur pada suatu alas hak yang selamanya ada padanya, penilaian kekuatan pembuktian surat bukan akta diberikan kepada hakim (Pasal 1881 ayat (2) KUHPerdata, Pasal 294 ayat (2) Rbg.). ${ }^{25}$

23 Samosir, Hukum Acara Perdata, hlm. 224.

24 Taufik Makarao, Pokok-Pokok Hukum Acara Perdata (Jakarta: Rineka Cipta, 2004), hlm. 101.

25 Mertokusumo, Hukum Acara Perdata Indonesia, hlm. 158-164. 
Terkait fungsinya sebagaialat pembuktian, kekuatan pembuktian akta dapat dibedakan menjadi tiga macam, yaitu pertama, kekuatan pembuktian formil, berdasarkan benar atau tidaknya pernyataan (bukan mengenai isi atau materi dari pernyataan itu) dalam akta. Pihak yang menandatangani akta menerangkan apa yang tertulis di dalam akta. Kedua, kekuatan pembuktian materiil, yang didasarkan atas benar atau tidaknya isi atau materi dari pernyataan yang ditanda tangani dalam akta, bahwa peristiwa hukum yang tertulis dalam akta tersebut benar telah terjadi, atau dengan kata lain kekuatan pembuktian materiil suatu akta akan memberikan kepastian tentang materi akta. Ketiga, kekuatan pembuktian lahir atau kekuatan pembuktian keluar, yang didasarkan atas keadaan lahir bahwa suatu surat yang secara fisik terlihat seperti akta, akan diterima atau dianggap seperti akta serta akan diperlakukan sebagai akta, sepanjang tidak terbukti sebaliknya. ${ }^{26}$

Menurut Pasal 165 HIR, Pasal 285 Rbg, atau Pasal 1870 dan 1871 KUHPerdata, akta otentik terhadap para pihak beserta ahli warisnya termasuk mereka yang memperoleh hak daripada akta otentik tersebut, merupakan bukti sempurna mengenai apa yang termuat di dalamnya, bahkan mengenai hal yang terdapat dalam akta sebagai penuturan belaka, namun tentang penuturan ini apabila yang dituturkan memiliki hubungan langsung dengan pokok akta. Jika tidak ada hubungan langsung, menurut Pasal 1871 KUHPerdata, hal itu hanya sebagai permulaan bukti tertulis. ${ }^{27}$ Kekuatan pembuktian lahir akta otentik berlaku juga bagi kepentingan dan terhadap pihak lain (tidak terbatas pada para pihak) ${ }^{28}$ atau oleh Subekti disebut dengan kekuatan pembuktian keluar (tehadap pihak ketiga). ${ }^{29}$ Dalam

26 Samudera, Hukum Pembuktian dalam Acara Perdata, hlm. 47 Sesuai dengan asas acta publica probant sese ipsa, yang berarti bahwa apabila suatu akta lahirnya (fisik) tampak sebagai akta otentik serta memenuhi syarat-syarat yang telah ditentukan, maka akta tersebut berlaku atau dapat dianggap sebagai akta otentik, kecuali dapat dibuktikan sebaliknya. Mertokusumo, Hukum Acara Perdata Indonesia, hlm. 161.

27 Mertokusumo, Hukum Acara Perdata Indonesia, hlm. 161.

28 Mertokusumo, Hukum Acara Perdata Indonesia, hlm. 161.

29 Subekti, Hukum Pembuktian, hlm. 30. 
arti formil, akta otentik memberikan bukti akan kebenaran mengenai apa yang dilihat, didengar, dan dilakukan pejabat yang membuat akta, yang membuktikan kebenaran keterangan pejabat perihal apa yang dilakukan dan dilihatnya. Kekuatan pembuktian formil memberikan kepastian mengenai tanggal atau waktu dan tempat dibuat akta tersebut serta membuktikan bahwa tanda tangan yang tertera adalah asli. ${ }^{30}$ Akta otentik bukan hanya membuktikan bahwa para pihak menerangkan mengenai apa yang tertulis dalam akta tersebut tetapi juga apa yang diterangkan adalah benar. ${ }^{31}$ Adapun hal-hal apat menurunkan derajat dan bentuk akta otentik menjadi akta di bawah tangan, adalah ${ }^{32}$ pejabat yang membuat tidak berwenang mebuat akta tersebut (Pasal 1869 KUHPerdata) dan/atau bentuknya cacat. ${ }^{33}$

Kekuatan pembuktian akta di bawah tangan diatur dalam Pasal

30 Mertokusumo, Hukum Acara Perdata Indonesia,, hlm. 162.

31 Oleh Subekti, kekuatan pembuktian materiil inilah yang dinamakan dengan kekuatan pembuktian mengikat yang membuktikan antara para pihak yang bersangkutan bahwa peristiwa yang disebutkan dalam akta adalah benar terjadi. Subekti, Hukum Pembuktian, hlm. 28-30

32 Harahap, Hukum Acara Perdata tentang Gugatan, hlm. 584.

33 Pasal 39 dan Pasal 40 Undang-Undang Nomor 30 Tahun 2004 tentangJabatan Notaris menentukan syarat bentuk akta yang dibuat dihadapan pejabat sehingga akta tersebut berlaku sebagai akta otentik. Syarat tersebut antara lain: 1) dilakukan dihadapan notaris; 2) usia minimal delapan belas tahun atau telah menikah serta cakap melakukan perbuatan hukum; 3) para pihak yang menghadap harus dikenal oleh notaris atau diperkenalkan kepada notaris yang bersangkutan oleh dua orang saksi berusia minimal delapan belas tahun atau telah menikah serta cakap melakukan perbuatan hukum atau dikenalkan oleh dua orang penghadap lainnya; 4) pengenalan tersebut dituliskan dengan tegas dalam akta; 5) notaris membacakan kembali isi akta, dan pada saat pembacaan tersebut harus dihadiri minimal dua orang saksi, kecuali ditentukan lain dalam peraturan perundang-undangan; 6) Saksi berusia minimal delapan belas tahun atau telah menikah serta cakap melakukan perbuatan hukum, mengerti bahasa yang digunakan dalam akta (Bahasa Indonesia), dapat memberikan tanda tangan dan paraf, tidak memiliki hubungan perkawinan atau hubungan darah dalam garis lurus ke atas atau ke bawah (tanpa pembatasan derajat) dan garis ke samping (sampai dengan derajat ketiga) dengan notaris atau para pihak; 7) Notaris harus mengenal sakis atau saksi harus diperkenalkan kepada notaris dan identitas serta kewenangannya harus diterangkan kepada notaris oleh penghadap. Apabila tidak memenuhi Pasal 39 dan 40 tersebut, maka kekuatan pembuktian hanya berlaku sebagai akta di bawah tangan (Pasal 41 UU Nomor 30 Tahun 2004). 
1876 KUHPerdata, yang menentukan bahwa tulisan atau akta di bawah tangan wajib diakui atau dipungkiri secara tegas tanda tangan dalam surat atau akta di bawah tangan tersebut. Diakuinya atau dipungkirinya tanda tangan tersebut dapat mempengaruhi kekuatan pembuktiannya. ${ }^{34}$ Jika tanda tangan disangkal, maka kebenaran akta tersebut harus diperiksa atas perintah hakim(Pasal 1877 KUHPerdata). Apabila tanda tangan diakui oleh yang bersangkutan, maka akta di bawah tangan tersebut mempunyai kekuatan dan menjadi bukti yang sempurna dan penyangkalan terhadap isi pernyataan di dalam akta di bawah tangan tidak dimungkinkan. ${ }^{35}$

Dikarenakan tanda tangan pada akta di bawah tangan masih dapat disangkal, akta di bawah tangan tidak memiliki kekuatan pembuktian lahir. ${ }^{36}$ Sehingga akta dibawah tangan tidak mengikat atau bebas terhadap pihak ketiga ${ }^{37}$ Kekuatan pembuktian formil dari akta di bawah tangan (yang diakui oleh yang bersangkutan) sama kuatnya seperti kekuatan pembuktian formil akta otentik. Sehingga menjadi suatu hal yang pasti bagi siapa pun bahwa yang menandatangani menyatakan sebagaimana yang tertulis di atas tanda tangan tersebut. ${ }^{38}$ Akta di bawah tangan yang diakui tanda tangannya, bagi mereka yang menandatangani, ahli warisnya serta orang-orang yang mendapat hak dari mereka, menjadi suatu bukti yang sempurna sama seperti akta otentik (Pasal 288 Rbg., atau Pasal 1875 KUHPerdata). Sehingga keterangan dalam akta di bawah tangan merupakan benar adanya bagi yang membuatnya dan bagi keuntungan orang kepada siapa si penanda tangan hendak memberikan bukti. Bagi pihak ketiga, kekuatan pembuktiannya bebas. ${ }^{39}$

Dengan demikian, jika tanda tangan dalam akta di bawah tangan tersebut dipungkiri atau disangkal, maka harus dilakukan pemeriksaan mengenai kebenaran tanda tangan tersebut dan kekuatan pembuktiannya bebas sampai didapatkannya kebenaran tanda

34 Subekti, Hukum Pembuktian, hlm. 29-30.

35 Mertokusumo, Hukum Acara Perdata Indonesia, hlm. 163.

36 Mertokusumo, Hukum Acara Perdata Indonesia, hlm. 163.

37 Subekti, Hukum Pembuktian, hlm. 30.

38 Mertokusumo, Hukum Acara Perdata Indonesia, hlm. 163.

39 Mertokusumo, Hukum Acara Perdata Indonesia, hlm. 164. 
tangan tersebut. Jika tanda tangan tersebut diakui, maka kekuatan pembuktiannya sama dengan kekuatan pembuktian akta otentik, memiliki kekuatan pembuktian formil dan materiil (sempurna dan mengikat). Akan tetapi, meskipun tanda tangan pada akta di bawah tangan telah diakui, akta di bawah tangan tersebut tidak memiliki kekuatan lahir (kekuatan pembuktian keluar) sehingga tidak mengikat pihak ketiga.

Kekuatan pembuktian surat bukan akta tidak diatur secara tegas dalamHIRmaupun KUHPerdata. Meskipun suratbukan aktamemang sengaja dibuat oleh yang bersangkutan, namun pada asasnya tidak bermaksud untuk dijadikan alat pembuktian dikemudian hari. Karena hal tersebut, surat bukan akta dapat digunakan sebagai petunjuk ke arah pembuktian, dalam arti surat bukan akta dapat digunakan sebagai alat bukti tambahan ataupun bisa juga dikesampingkan, bahkan tidak dapat dipercaya. Dengan demikian, agar surat bukan akta dapat memiliki kekuatan pembuktian, sepenuhnya tergantung kepada penilaian hakim sebagaimana diatur dalam Pasal 1881 ayat (2) KUHPerdata. ${ }^{40}$

Namun demikian, undang-undang mengatur beberapa surat bukan akta yang dapat digunakan sebagai alat bukti yang mengikat dalam arti harus dipercayai oleh hakim (Pasal 1881 dan 1883 KUHPerdata), yaitu pertama, apabila surat tersebut menyebutkan dengan tegas mengenai suatu pembayaran yang telah diterima. Kedua, apabila surat yang bersangkutan dengan tegas menerangkan catatan yang dibuat dilakukan untuk memperbaiki kekurangan dalam suatu alas hak seseorang demi keuntungan siapa surat itu menyebutkan suatu perikatan. Ketiga, setiap catatan yang dibubuhkan kreditur pada suatu alas hak yang selamanya dipegangnya, dan bila yang ditulis itu merupakan suatu pembebasan terhadap debitur. Keempat, catatan yang dibubuhkan debitur dalam salinan dan suatu alas hak atau suatu tanda pembayaran, dengan ketentuan salinan atau tanda pembayaran tersebut ada dalam penguasaan kreditur. Hakim harus percaya kepada tulisan-tulisan atau catatan-catatan tersebut selama

40 Samudera, Hukum Pembuktian dalam Acara Perdata, hlm. 54. 
pembuatnya tidak dapat membuktikan bahwa tulisan atau catatan tadi dibuat secara keliru atau dibuat oleh orang lain dengan maksud untuk merugikan dia. ${ }^{41}$

Kekuatan pembuktian suatu tulisan pada dasarnya terdapat pada asli akta tersebut (Pasal 301 Rbg. dan Pasal 1888 KUHPerdata). Apabila asli dari suatu akta tersebut ada, maka salinan atau ikhtisar hanya dapat dipercaya apabila salinan atau ikhtisar tersebut sesuai dengan aslinya yaitu dengan cara menunjukan dan dicocokkan dengan aslinya. Apabila akta yang asli tidak ada lagi (telah hilang) maka beberapa salinan berikut ini bisa memberikan bukti yang sama dengan aslinya, yaitu: 1) salinan pertama, 2) salinan yang dibuat atas perintah hakim dan dihadiri para pihak, atau setelah para pihak tersebut dipanggil secara sah, 3) salinan yang tanpa perantaraan hakim atau di luar persetujuan para pihak, dan setelah salinan pertama dikeluarkan, dibuat oleh notaris, oleh pegawai-pegawai yang dalam jabatannya menyimpan akta asli dan berwenang memberikan salinan. Selain ketiga hal tersebut, maka salinan hanya berlaku sebagai permulaan pembuktian dan kekuatan pembuktiannya diserahkan kepada hakim (Pasal 302 Rbg. dan Pasal 1889 KUHPerdata). ${ }^{42}$ Ketentuan lainnya bahwa suatu tembusan surat yang dibuat dengan kertas karbon memiliki kekuatan sama seperti aslinya, karena tembusan tersebut sama dengan surat pada halaman pertama yang ditulis dengan pensil atau pena yang langsung berhubungan dengan tembusan tersebut. ${ }^{43}$

Terhadap salinan-salinan yang berlaku sebagai permulaan pembuktian, bisa diterima sebagai alat bukti jika dapat dicocokkan dengan aslinya. Menurut M. Yahya Harahap, apabila aslinya tidak ada maka dapat dibantu dengan alat bukti lain. Namun tidak semua alat bukti dapat digunakan, melainkan terbatas pada alat bukti surat dan saksi. Alat bukti sumpah tidak dapat digunakan karena alat bukti sumpah dianggap dapat mengganggu ketertiban umum, bagi seorang yang curang dan beritikad buruk, apalagi bermoral rendah, mungkin saja

41 Subekti, Hukum Pembuktian, hlm. 35.

42 Subekti, Hukum Pembuktian, hlm. 36.

43 Mertokusumo, Hukum Acara Perdata Indonesia, hlm. 166. 
memanfaatkan sumpah untuk menguatkan salinan palsu. ${ }^{44}$

Fotokopi adalah "suatu hasil reproduksi (penggandaan) fotografis terhadap barang cetakan (tulisan), sedangkan yang dimaksud dengan memfotokopi adalah membuat reproduksi dengan mesin fotokopi" ${ }^{45}$ Ini berarti, fotokopi merupakan penggandaan suatu surat yang mana penggandaan tersebut dilakukan dengan menggunakan mesin fotokopi.

Dalam praktik pada tahap pembuktian di Pengadilan, alat bukti tulisan yang diajukan ke persidangan biasanya bukanlah tulisan aslinya, melainkan hanya fotokopi yang telah dilegalisasi oleh panitera pengadilan (fotokopi surat akan diterima secara formil dan dilakukan pemateraian [nazegeling]) sedangkan tulisan aslinya ditunjukkan pada persidangan. Praktik tersebut menyesuaikan dengan perkembangan zaman serta kemajuan teknologi yang telah mengenal mesin fotokopi, dan tidak akan ada keberatan apabila fotokopi tersebut betul-betul sesuai dengan aslinya. ${ }^{46}$ Akan tetapi, ada kalanya surat aslinya tidak ada atau hilang dan para pihak hanya memiliki fotokopi surat yang ia butuhkan guna membuktikan dalilnya, sehingga para pihak hanya dapat mengajukan fotokopi surat tersebut ke dalam persidangan.

Terkait macam-macam alat bukti sebagaimana diatur dalam Pasal 164 HIR, Pasal 284 Rbg., atau 1866 KUHPerdata dan dikaitkan dengan pendapat Subekti, antara lain menyatakan bahwa pernah dipermasalahkan mengenai apakah selain lima macam alat bukti yang disebutkan oleh Pasal 164 HIR, Pasal 284 Rbg., atau 1866 KUHPerdata tersebut tidak terdapat lagi alat-alat bukti lainnya. Permasalahan tersebut biasanya dijawab bahwa alat-alat bukti yang ditentukan dalam pasal-pasal tersebut bukan berarti melarang alatalat bukti lainnya yang bukan tulisan. Perlu diingat pula bahwa ketentuan yang digunakan saat ini dibuat seratus tahun yang lalu. Dengan adanya kemajuan teknologi yang pesat muncul beberapa

44 Harahap, Hukum Acara Perdata tentang Gugatan, hlm. 619.

45 https://kbbi.kemdikbud.go.id/entri/fotokopi dan https://kbbi. kemdikbud.go.id/entri/memfotokopi.

46 Riduan Syahrani, Hukum Acara Perdata di Lingkungan Peradilan Umum (Jakarta: Pustaka Karini, 1988), hlm. 65. 
teknologi baru, seperti fotokopi, tape recorder, dan teknologi lainnya yang dapat dipergunakan sebagai alat bukti. ${ }^{47}$ Maka sesuai dengan pendapat tersebut nampak diakuinya bukti fotokopi sebagai alat bukti diluar Pasal 184 HIR. ${ }^{48}$

Menurut Teguh Samudera, suatu salinan, fotokopi, dan kutipan dapat mempunyai nilai kekuatan pembuktian sepanjang kutipan, salinan, atau fotokopi itu sesuai dengan aslinya. ${ }^{49}$ Demikian pula dengan Riduan Syahrani yang tidak berkeberatan terhadap pengajuan fotokopi surat dengan syarat fotokopi tersebut telah dilegalisasi oleh panitera pengadilan dan dengan menunjukan surat aslinya di persidangan untuk mencocokkan fotokopi surat tersebut dengan surat aslinya. ${ }^{50}$

Demikian pula M. Yahya Harahap, yang berpendapat salinan dan fotokopi hampir tidak ada bedanya. Perbedaan pokok hanya terletak pada instrumen yang digunakan. Pada salinan, yang digunakan adalah peralatan konvensional secara manual, sedangkan pada fotokopi, yang digunakan sistem dan peralatan elektronik yang canggih. Ditinjau dari segi pendekataan persamaan atau persesuaian, hasil fotokopi jauh lebih tinggi kualitas identik atau kesamaannya dibandingkan dengan salinan yang menggunakan cara konvensional baik manual maupun dengan salinan tulis tangan. Akan tetapi kekuatan pembuktian salinan jauh lebih tinggi dibandingkan dengan fotokopi karena mengenai salinan diatur dalam undang-undang sedangkan fotokopi tidak. Mengenai salinan terdapat dalam Pasal 1889 KUHPerdata atau $302 \mathrm{Rbg}$, yang memberikan kedudukan suatu salinan sama dengan aslinya. Sehingga nilai kekuatan pembuktian salinan pertama (grosse pertama) sama seperti nilai kekuatan pembuktian surat aslinya. Sedangkan ketentuan mengenai sejauh mana kesamaan atau identiknya fotokopi dengan aslinya belum ada. ${ }^{51}$

47 Subekti, Hukum Pembuktian, hlm. 22

48 Mahkamah Agung Republik Indonesia, Yurisprudensi Mahkamah Agung RI Tahun 2010 (Jakarta: Badan Penelitian dan Pengembangan \& Pendidikan dan Pelatihan Hukum dan Peradilan, 2010), hlm. 39.

49 Samudera, Hukum Pembuktian dalam Acara Perdata, hlm. 57.

50 Syahrani, Hukum Acara Perdata, hlm. 65.

51 Harahap, Hukum Acara Perdata tentang Gugatan, hlm. 622. 
Menurut yurisprudensi Putusan Mahkamah Agung Nomor 701 K/Sip/ 1974 tanggal 14 April 1976, ${ }^{52}$ Putusan Mahkamah Agung Nomor 3609 K/Pdt/ 1985 tanggal 9 Desember 1987,, ${ }^{53}$ dan Putusan Mahkamah Agung Nomor $2191 \mathrm{~K} / \mathrm{Pdt} / 2000$ tanggal 14 Maret 2001,54 dalam mengajukan fotokopi surat-surat sebagai alat bukti di dalam persidangan gugatan perdata di Pengadilan harus dinyatakan telah sesuai (dicocokkan) dengan aslinya. Bila tidak demikian, maka bukti surat berupa fotokopi tersebut merupakan alat bukti yang tidak sah dalam persidangan. Dari uraian tersebut, baik pendapat ahli maupun menurut yurisprudensi, dapat disimpulkan bahwa fotokopi merupakan suatu penggandaan tulisan/surat dan dapat diterima sebagai alat bukti tulisan/surat apabila telah dicocokkan dengan aslinya di persidangan.

\section{Fotokopi Surat yang Tidak Dapat Dicocokkan dengan Surat Aslinya dalam Perkara Perdata dan Kekuatan Pembuktiannya}

Bagian ini akan mendiskusikan status hukum fotokopi surat yang tidak dapat dicocokkan dengan aslinya dalam perkara perdata, sekaligus dibahas kekuatan pembuktiannya. Dalam mendiskusikan persoalan tersebut, dua putusan pengadilan akan dijadikan sebagai bahan utamanya. Kedua putusan tersebut adalah Putusan Pengadilan Negeri Jakarta Pusat Nomor 164/Pdt.G/2004/PN.Jkt.Pst jo. Putusan Pengadilan Tinggi Jakarta Nomor 234 / Pdt/ 2005 / PT.DKI jo. Putusan Mahkamah Agung Nomor 1498 K/Pdt/ 2006 dan Putusan Pengadilan Negeri Pontianak Nomor 52/Pdt.G/2003/ PN.Ptk.

Sebelum menguraikan dan membahas kedua putusan tersebut,

52 R. Soeroso, Hukum Acara Perdata Lengkap dan Praktis HIR, Rbg., dan Yurisprudensi (Jakarta: Sinar Grafika, cetakan kedua, 2011), hlm. 118.

53 Harahap, Hukum Acara Perdata tentang Gugatan, hlm. 622.

54 Tergugat dalam persidangan mengajukan bukti surat berupa fotokopi Sertifikat Hak Pakai yang tidak dapat ditunjukan sertifikat aslinya dalam persidangan. Menurut hakim, secara yuridis fotokopi Sertifikat Hak Pakai Tanah tersebut tidak dapat diterima sebagai alat bukti yang sah dalam perkara gugatan tersebut. Boediarto, Kompilasi Kaidah Hukum Putusan, hlm. 154. 
perlu disampaikan kembali bahwa pada prinsipnya berdasarkan yurisprudensi Putusan Mahkamah Agung maka suatu fotokopi surat hanya dapat diterima pada persidangan apabila telah dicocokkan dengan aslinya. Namun demikian, Putusan Mahkamah Agung Nomor $112 \mathrm{~K} / \mathrm{Pdt} / 1996$ tanggal 17/9/1998 ternyata juga mengakomodasi fotokopi surat yang tidak dapat dicocokkan dengan aslinya, dengan syarat dikuatkan dengan alat bukti lain. Jika tidak dapat dikuatkan dengan alat bukti lainnnya, maka fotokopi surat tidak dapat diterima sebagai alat bukti yang sah. ${ }^{55}$ Dengan alasan tersebut, menurut M. Yahya Harahap, suatu fotokopi surat yang diajukan di dalam persidangan dapat diterima sebagai alat bukti yang sah apabila dapat dicocokkan dengan aslinya atau dikuatkan dengan alat bukti lain. ${ }^{56}$

Mahkamah Agung dalam putusannya Nomor $410 \mathrm{~K} / \mathrm{pdt} / 2004$ tanggal 25/4/2005 juga menerima fotokopi surat sebagai alat bukti yang sah dalam pengadilan dikarenakan telah diakui dan dibenarkan oleh pihak lawan. Dalam perkara sengketa Rektor melawan Yayasan di Universitas Trisakti, hakim memberikan pertimbangan bahwa suatu surat berupa fotokopi yang diajukan pada persidangan sebagai bukti oleh salah satu pihak, penggugat atau tergugat, meskipun tidak dapat diperlihatkan surat aslinya. Namun demikian, karena fotokopi surat tersebut telah diakui dan dibenarkan oleh pihak lawan, maka ia dapat diterima sebagai alat bukti surat yang sah di dalam persidangan. ${ }^{57}$

Penerimaan fotokopi surat yang tidak dapat dicocokkan dengan aslinya tetapi dikuatkan dengan pengakuan pihak lawan, terdapat dalam Putusan Pengadilan Negeri Jakarta Pusat Nomor 164/Pdt.G/2004/PN.Jkt.Pst jo. Putusan Pengadilan Tinggi Jakarta Nomor 234/Pdt/2005/PT.DKI jo. Putusan Mahkamah Agung Nomor 1498 K/Pdt/2006. Dalam perkara ini, Penggugat (Masnin binti Samit) mengajukan fotokopi dari fotokopi Girik C Nomor 721 dengan luas $1.500 \mathrm{~m}^{2}$ sebagai bukti kepemilikan girik tersebut, dikarenakan asli girik ada pada Tergugat Tiga (PT. Pertamina Tbk). Majelis Hakim pada tingkat pertama tidak serta merta menolak

55 Boediarto, Kompilasi Kaidah Hukum Putusan, hlm. 152-153.

56 Harahap, Hukum Acara Perdata tentang Gugatan, hlm. 623.

57 Boediarto, Kompilasi Kaidah Hukum Putusan, hlm. 155. 
atau mengenyampingkan bukti fotokopi Girik C yang tidak dapat dicocokkan dengan aslinya ini. Majelis mengaitkan bukti fotokopi girik tersebut dengan pengakuan Tergugat Tiga dalam jawabannya, bahwa "sudah merupakan konsekuensi hukum jual beli untuk menyerahkan Girik berikut tanah tersebut dari penjual kepada pembeli yang dalam hal ini dari Tergugat Satu selaku kuasa yang bertindak untuk dan atas nama Samit / Amit bin Kibi kepada Tergugat Dua dan kemudian Tergugat Dua menjual tanah girik a quo kepada Tergugat Tiga”. Majelis Hakim mempertimbangkan bahwa terkait pengakuan dengan klausula tersebut Penggugat harus membuktikan ketidakbenaran keterangan tambahan pada pengakuan Tergugat Tiga, dan jika Penggugat dapat membuktikannya maka pengakuan dengan klausula tersebut berubah menjadi pengakuan murni sebagaimana dimaksud dalam Pasal 313 HIR. ${ }^{58}$

Terhadap keterangan tambahan dalam jawaban Tergugat Tiga, Majelis Hakim berpendapat bahwa surat kuasa menjual dari Samit kepada Tergugat Satu adalah cacat hukum karena Samit telah meninggal pada tahun 1963, sedangkan surat kuasa menjual tersebut tertanggal 13/6/1970. Dengan demikian surat kuasa menjual yang mendasari perbuatan hukum Tergugat Satu

58 Pengakuan dengan klausula haruslah diterima seluruhnya secara penuh dan tidak dapat dipisahkan dari keterangan tambahannya (onsplitsbare aveu) (ketentuan ini terdapat dalam Pasal 176 HIR, Pasal 313 Rbg., atau Pasal 1924 KUHPerdata). Pasal 176 HIR menyebutkan bahwa "tiap pengakuan harus diterima keseluruhannya dan hakim tidak bebas untuk menerima sebagian dan menolak selebihnya, sehingga merugikan yang memberikan pengakuan. Hal demikian hanya boleh dilakukan kalau orang yang berhutang, dengan maksud untuk membebaskan dirinya, menyebutkan peristiwa yang terbukti tidak benar." Sudikno Mertokusumo menjelaskan bahwa jika tergugat memberikan pengakuan yang tidak dapat dipisahpisahkan, penggugat harus memilih sikap 1) menolak pengakuan tersebut seluruhnya dan memberikan pembuktian sendiri, atau 2) membuktikan bahwa keterangan tambahan pada pengakuan itu adalah tidak benar. Kalau berhasil dibuktikan maka penggugat dapat memohon kepada hakim untuk memisahkan pengakuan tergugat dari keterangan tambahan tergugat yang telah terbukti tidak benar tersebut. Karena dilakukannya pemisahan tersebut, pengakuan tergugat menjadi pengakuan biasa (murni), Pasal 313 HIR, yang mempunyai kekuatan pembuktian yang sempurna dan mengikat. Mertokusumo, Hukum Acara Perdata Indonesia, hlm. 185. 
adalah tidak benar atau setidak-tidaknya batal demi hukum karena menurut Pasal 1813 KUHPerdata, surat kuasa menjadi gugur dengan meninggalnya pemberi kuasa sehingga segala perbuatan hukum yang dilakukan Tergugat Satu berdasarkan surat kuasa tersebut yang mengatasnamakan Samit/Amit bin Kibi menjadi batal demi hukum. Dengan terbuktinya bahwa perbuatan hukum pelepasan hak atas tanah a quo dari Tergugat Satu (yang mengaku mengatasnamakan Samit) kepada Tergugat Dua tidak sah dikarenakan surat kuasa penjualan yang cacat hukum, maka surat kuasa menjual tersebut, yaitu akta Nomor 25 tanggal 20 Juni 1970 serta akta-akta turunannya yang dibuat berdasarkan akta Nomor 25 tersebut dinyatakan batal demi hukum. ${ }^{59}$ Dengan demikian keterangan tambahan yang melekat pada pengakuan Tergugat Tiga terbukti tidak benar, sehingga pengakuan dengan klausula tersebut berubah menjadi pengakuan murni yang berarti Tergugat Tiga mengakui bahwa tanah a quo adalah milik Alm. Samit/Amit bin Kibi, ayah Penggugat.

Oleh karena bukti fotokopi Girik C Nomor 721 atas nama Amit bin Kibi dengan luas $1.500 \mathrm{~m}^{2}$, fotokopi Girik C No. 718 atas nama Samit bin Kibi, fotokopi keterangan dan peta rincian tanah di Kelurahan Duri Kecamatan Kebon Jeruk, Jakarta Barat, dan fotokopi gambar situasi Nomor 1/1217/ 1970, telah bersesuaian dengan Pengakuan Tergugat Tiga, maka dapat diterima sebagai bukti yang sah. Bukti fotokopi tersebut selanjutnya digunakan untuk menunjang pengakuan Tergugat Tiga, sehingga dapat dikatakan bahwa fotokopi tersebut memberikan kekuatan pembuktian yang bebas.

Dalam perkara ini Majelis Hakim juga menerima fotokopi akta pelepasan hak yang tidak dicocokkan dengan asli suratnya sebagai bukti. Penerimaan fotokopi akta pelepasan hak ini dikarenakan telah bersesuaian dengan pengakuan bahwa memang telah terjadi pelepasan hak serta telah bersesuaian dengan bukti lainnya, sehingga

59 Karena terdapat kekhilafan, perjanjian jual beli tanah tersebut berakibat hukum batal (Pasal 1321 KUHPerdata). Meskipun terdapat pembaharuan perjanjian jual beli pada tanggal 10 Oktober 1970, tidak menghilangkan unsur kekhilafan tersebut (pertimbangan Majelis Hakim Pengadilan Negeri Jakarta Pusat dalam Putusan No. 164/Pdt.G/2004/PN.Jkt.Pst). 
fotokopi tersebut dapat diterima sebagai alat bukti dan memberikan kekuatan pembuktian yang bebas. Penerimaan bukti fotokopi ini mirip dengan kasus pada Putusan Mahkamah Agung Nomor $410 \mathrm{~K} /$ pdt/2004 tanggal 25 April 2005.

Pada tingkat banding, putusan Pengadilan Negeri Jakarta Pusat tersebut dibatalkan. Majelis Hakim tingkat banding menyatakan bahwa Majelis Hakim pada tingkat pertama telah memutus perkara berdasarkan alat bukti yang tidak sah, yaitu bukti berupa fotokopi dari fotokopi (maksudnya bukti fotokopi yang tidak dicocokkan dengan surat aslinya) yang secara substansial masih dipersengketakan. Begitu pula dengan bukti fotokopi dari fotokopi lainnya, karena tidak dicocokkan dengan surat aslinya sehingga tidak diterima sebagai alat bukti yang sah. Dasar pertimbangannya adalah Pasal 1888 KUHPerdata serta Putusan Mahkamah Agung Nomor $701 \mathrm{~K} / \mathrm{Sip} / 1976$ tanggal 14/4/1976. Majelis Hakim tingkat banding menolak bukti fotokopi yang tidak dicocokkan dengan aslinya tersebut tanpa memperhatikan fakta-fakta hukum lain yang terjadi dalam persidangan. Majelis Hakim pada tingkat banding tidak melihat pada alat bukti pengakuan, baik pengakuan Tergugat Tiga maupun pengakuan Penggugat akan adanya pembebasan tanah a quo pada tahun 1970 terhadap bukti fotokopi akta pelepasan hak. Majelis Hakim tingkat banding juga tidak melihat kepada yurisprudensi yang lebih baru yaitu Putusan MA Nomor 112 K/Pdt/ 1996 yang memungkinkan penerimaan fotokopi sebagai alat bukti apabila bersesuaian dengan alat bukti lain juga Putusan MA Nomor 410 K/Pdt / 2004 yang menerima fotokopi sebagai alat bukti karena bersesuaian dengan pengakuan pihak lawan.

Pada tingkat kasasi, Mahkamah Agung berpendapat bahwa Pengadilan Tinggi Jakarta salah menerapkan hukum sebab tidak memberikan pertimbangan yang cukup. Alasannya karena Majelis Hakim pada tingkat banding tidak melihat dalam konteks apa bukti fotokopi tersebut diterima oleh Majelis Hakim Pengadilan Negeri Jakarta Pusat. Pertimbangan Majelis Hakim tingkat banding dinilai keliru karena Majelis Hakim pada tingkat pertama menggunakan alat bukti fotokopi tersebut untuk menunjang pengakuan Tergugat 
Tiga dalam jawabannya. Menurut Mahkamah Agung, bukti fotokopi yang tidak dicocokkan dengan aslinya tersebut diterima sebagai alat bukti serta memiliki kekuatan pembuktian yang bebas, dan alat bukti fotokopi tersebut oleh Majelis Hakim pada tingkat pertama digunakan dalam konteks untuk menunjang pengakuan Tergugat Tiga. Majelis Hakim pada tingkat pertama tidak memutus berdasarkan alat bukti fotokopi tersebut secara berdiri sendiri, melainkan dikaitkan dengan Pengakuan Tergugat Tiga.

Penerimaan fotokopi surat yang tidak dapat dicocokkan dengan aslinya tetapi dikuatkan dengan alat bukti keterangan saksi dijumpai juga dalam Putusan Pengadilan Negeri Pontianak Nomor 52/ Pdt.G/2003/PN.Ptk dalam perkara Perdata antara A. Karim dkk. (yang merupakan ahli waris dari Rahmah binti Kacung) sebagai Para Penggugat melawan Kepala Dinas Pendidikan Propinsi Kalimantan Barat sebagai Tergugat Satu, Kepala Pertanahan Kota Pontianak sebagai Tergugat Dua, dan Walikota Pontianak sebagai Tergugat Tiga, serta Kepala Pos Babinsa, Hermawan, Cak Nan, Usman, juraisyah, Busri, Tan Sun Heng, Asuardy, Harris Ng, Syafiansyah, Isminingsih, dan Djemain sebagai Turut Tergugat Satu sampai dengan Sebelas. Obyek sengketa dalam perkara ini adalah tanah berdasarkan alas hak tanah yaitu Surat Pemberian Tanah tertanggal 10 Desember 1940 bertulisan Arab Melayu dan telah diterjemahkan ke dalam Bahasa Indonesia serta telah didaftarkan pada Pengadilan Agama Pontianak dengan register Nomor 2/SAM/2002/PA.PTK tanggal 18/12/2002.

Guna membuktikan bahwa tanah a quo adalah miliknya, Penggugat mengajukan bukti fotokopi Surat Pemberian Tanah berbahasa arab melayu dan bukti fotokopi Terjemahan Surat Pemberian Tanah yang keduanya tidak dapat dicocokkan dengan aslinya. Penggugat menjelaskan bahwa surat aslinya telah hilang berdasarkan Laporan Kehilangan dari Poltabes Sektor Kota Pontianak Selatan Nomoro POL.STPLKB/548/B/VI/2003 tanggal 15/6/2003. Bukti fotokopi tersebut diterima oleh Majelis Hakim karena bersesuaian dengan keterangan saksi Nurdin yang menyatakan bahwa ia menerjemahkan surat pemberian tanah tersebut dari bahasa Arab Melayu ke dalam bahasa Indonesia yang isinya menerangkan bahwa Abdullah Latif 
memberikan tanah a quo kepada adik sepupunya, yaitu Rahmah binti Kacung pada tanggal 10/12/1940. Saksi (Nurdin) juga menyatakan, sewaktu Penggugat datang kepadanya (Desember 2002) untuk menerjemahkan surat tersebut, Penggugat membawa surat aslinya. Saksi lainnya yang diajukan Penggugat juga menerangkan bahwa ia pernah melihat surat aslinya sebelum surat tersebut hilang. Hilangnya surat pemberian tanah (asli) dan terjemahannya (asli) telah dilaporkan ke Poltabes Sektor Kota Pontianak.

Dalam mempertimbangkan alat bukti yang diajukan Penggugat, Majelis Hakim menimbang bahwa meskipun surat pemberian tanah dan terjemahan surat pemberian tanah hanya berupa fotokopi yang tidak dicocokkan dengan aslinya, keduanya didukung dengan keterangan saksi. Selain itu Penggugat juga mengajukan bukti surat berupa pernyataan dari Para Turut Tergugat yang menyatakan bahwa mereka telah menggunakan tanah ahli waris Rahmah binti Kacung, yang mana bukti surat tersebut merupakan suatu pengakuan yang memiliki kekuatan pembuktian yang sempurna, sehingga bersesuaian dengan fotokopi surat pemberian tanah dan terjemahan surat pemberian tanah yang diajukan oleh Penggugat. Berdasarkan pertimbangan tersebut, Majelis Hakim menerima fotokopi surat tersebut dan menggunakan sebagai dasar menyatakan Penggugat sebagai pemilik sah atas tanah a quo, alat bukti fotokopi tersebut tidak berdiri sendiri, tetapi dikuatkan dengan alat bukti lain.

Pada tingkat banding, putusan Pengadilan Negeri Pontianak tersebut dibatalkan. Majelis Hakim tingkat banding berpendapat karena bukti fotkopoi tersebut tidak ada aslinya, sedangkan kekuatan pembuktian bukti tulisan ada pada asli suratnya (Pasal 1888 KUHPerdata) maka ia tidak mempunyai kekuatan pembuktian dan harus dikesampingkan. Jika disandingkan dengan alat bukti para Tergugat berupa sertifikat hak pakai, maka jelas alat bukti tersebut membuktikan bahwa tanah sengketa adalah milik Tergugat Satu. Lagi pula, sebelum menerbitkan sertifikat tersebut, Tergugat Dua tentu saja telah melalui tahap-tahap seperti yang diatur dalam Peraturan Menteri Agraria Nomor 8 Tahun 1961 jo PP Nomor 24 Tahun 1997.

Selain itu, Pasal 32 ayat (2) PP No. 24 Tahun 1997 menyebutkan 
bahwa "suatu bidang tanah yang sudah diterbitkan sertifikat secara sah, baik atas nama orang maupun badan hukum, yang memperoleh tanah tersebut dengan itikad baik serta secara nyata menguasainya, maka pihak lain yang merasa memiliki hak atas tanah itu tidak dapat lagi menuntut pelaksanaan hak tersebut jika dalam kurun waktu lima tahun sejak diterbitkannya sertifikat tersebut tidak mengajukan keberatan tertulis kepada pemegang sertifikat serta kepada kantor pertanahan yang bersangkutan atau tidak mengajukan gugatan ke Pengadilan terkait penguasaan tanah atau penerbitan sertifikat tersebut." ${ }^{60}$ Penggugat sendiri baru mengajukan tanggal 9 Agustus 2003, atau sudah tujuh tahun tujuh bulan sejak diterbitkannya sertifikat tersebut (9/1/1996), dalam arti gugatannya telah lampau waktu. Pertimbangan lainnya, bahwa sita jaminan yang dilakukan Majelis Hakim Pengadilan Negeri tidaklah sah karena tanah yang disita adalah tanah Negara dan seharusnya mendapat izin terlebih dahulu dari Mahkamah Agung.

Pada tingkat Kasasi, Mahkamah Agung berpendapat bahwa judex facti tidak salah menerapkan hukum yang berlaku. Terkait penilaian hasil pembuktian yang merupakan penghargaan atas

60 Hingga sekarang belum ada kesepakatan antara para hakim terkait penerapan Pasal 32 ayat (2) PP Nomor 24 Tahun 1997. Penerapan pasal ini masih bergantung pada pertimbangan hakim apakah akan membawa keadilan bagi pihak yang bersengketa. Karena adanya benturan antara dua kepentingan yaitu jika penggugat benar-benar merupakan pemilik hak atas tanah yang sebenarnya dan tergugat benar telah memperoleh hak atas tanahnya dengan itikad baik. Sehingga penerapan pasal ini pada penyelesaian sengketa tanah diserahkan pada hakim yang mengadili perkara. Biasanya praktisi yang berkaitan langsung dengan penyelesaian masalah hukum, yaitu hakim dan pengacara tidak setuju untuk meterapkan pasal ini, karena khawatir menimbulkan ketidakadilan. Karenakan pemilik hak yang sebenarnya bisa kehilangan hak yang sebenarnya ia miliki. Sedangkan di sisi lain, masyarakat yang memiliki sertifikat dan Pejabat Pembuat Akta Tanah serta Pejabat Kantor Pertanahan setuju dalam menerapkan pasal ini karena dianggap akan menjamin perlindungan dan kepastian hukum bagi pihak yang mendaftarkan haknya sesuai dengan tujuan pendaftaran tanah. Lihat Erpinka Apriani, "Kepastian Hukum Sertipikat Hak Atas Tanah Kaitannya dengan Ketentuan Pasal 32 ayat (2) Peraturan Pemerintah Nomor 24 Tahun 1997 tentang Pendaftaran Tanah”, (tesis, Universitas Diponegoro, Semarang, 2007), hlm. 89. 
suatu kenyataan, disebut Mahkamah Agung bukan menjadi wewenang dalam tingkat kasasi untuk mepertimbangkannya. Oleh karena penilaian terhadap bukti yang diajukan atau penilaian hasil pembuktian bukan merupakan wewenang judex yuris (Mahkamah Agung), maka hal tersebut tidak dapat dipertimbangkan pada tingkat kasasi.

Putusan Pengadilan Negeri Jakarta Pusat Nomor 164/ Pdt.G/2004/ PN.Jkt.Pst jo. Putusan Pengadilan Tinggi Jakarta Nomor 234/Pdt/2005/PT.DKI jo. Putusan Mahkamah Agung Nomor 1498 $\mathrm{K} / \mathrm{Pdt} / 2006$ merupakan contoh penerimaan persidangan suatu fotokopi surat yang tidak dapat dicocokkan dengan aslinya namun dikuatkan dengan pengakuan pihak lawan. Sedangkan Putusan Pengadilan Negeri Pontianak Nomor 52 / Pdt.G / 2003/ PN.Ptk merupakan contoh penerimaan di persidangan suatu fotokopi surat yang tidak dapat dicocokkan dengan aslinya tetapi dikuatkan dengan alat bukti keterangan saksi. Pada kedua perkara tersebut, selain kaidah bahwa fotokopi surat yang tidak dapat dicocokkan dengan aslinya dapat diterima sebagai alat bukti yang sah apabila dikuatkan dengan alat bukti lain yang sah sebagaimana yurisprudensi dalam Putusan Nomor 112 K/Pdt/ 1996 dan Putusan Nomor 410 K/pdt/2004, terdapat penegasan bahwa penggunaan bukti fotokopi surat tersebut sebagai dasar Majelis Hakim dalam memutus tidaklah digunakan secara berdiri sendiri melainkan sebagai penunjang atau dikaitkan dengan alat bukti lainnya yang sah. Dalam perkara pertama, Mahkamah Agung menegaskan bahwa Majelis Hakim pada tingkat pertama tidak memutus berdasarkan fotokopi surat tersebut secara berdiri sendiri melainkan digunakan dalam konteks untuk menunjang pengakuan (Tergugat Tiga). Dalam perkara kedua, meski pada akhirnya dibatalkan oleh Pengadilan Tingkat Banding dengan alasan keberatan atas penerbitan sertifikat hak pakai milik tergugat telah lewat waktu, fotokopi surat yang tidak dapat dicocokkan dengan surat aslinya yang diterima sebagai alat bukti karena dikuatkan dengan alat bukti keterangan saksi (dua orang saksi, yaitu saksi Nurdin dan saksi Jemain). Hal ini berarti, fotokopi surat yang tidak dapat dicocokkan dengana slinya tidak digunakan secara berdiri sendiri, melainkan 
dikaitkan dengan alat bukti lainnya yaitu alat bukti keterangan saksi, alat bukti surat berupa surat laporan kehilangan, serta alat bukti pengakuan para turut tergugat.

Dalam suatu kumpulan yurisprudensi, Mahkamah Agung menegaskan bahwa fotokopi surat yang diajukan ke persidangan dan dikuatkan dengan alat bukti lainnya yang sah maka bisa diterima sebagai alat bukti yang sah dan memiliki kekuatan pembuktian yang bebas dalam artian penilaiannya diserahkan kepada hakim yang memeriksa perkara. Mahkamah Agung juga menambahkan, "tentu saja dalam melakukan penilaian tersebut, fotokopi surat tidak bisa berdiri sendiri, tetapi dikaitkan dengan alat bukti lainnya yang relevan." ${ }^{61}$ Hal ini seharusnya menjadi catatan bahwa meskipun fotokopi surat yang tidak dapat dicocokkan dengan surat aslinya dapat diterima sebagai alat bukti karena dikuatkan dengan alat bukti lainnya dan hakim bebas memberikan penilaian terhadap kekuatan pembuktian fotokopi surat tersebut, hakim dalam pertimbangannya ternyata tidak boleh memutus berdasarkan fotokopi tersebut secara berdiri sendiri. Fotokopi tersebut harus menjadi penunjang atau dikaitkan dengan alat bukti lainnya yang sah.

Penerimaan fotokopi surat yang tidak dapat dicocokkan dengan aslinya sebagai alat bukti yang sah karena dikuatkan dengan alat bukti lainnya diharapkan dapat menampung persoalan yang terkadang terjadi karena hal-hal di luar kuasa manusia, seperti hilang karena banjir, kebakaran, atau bencana lainnya, atau juga dikarenakan halhal lain yang menyebabkan hilangnya dokumen. Dengan demikian, pemilik dokumen tetap mendapatkan haknya atas dokumen yang aslinya telah hilang tersebut. Dalam hal ini hakim diberikan kebebasan dalam menilai seberapa kuat alat-alat bukti yang diajukan para pihak, namun perlu juga diperhatikan bahwa fotokopi surat tidak digunakan secara berdiri sendiri karena dapat mencederai kepastian hukum dalam sistem pembuktian, yaitu sistem pembuktian positif (berdasarkan undang-undang). ${ }^{62}$

61 Mahkamah Agung, Yurisprudensi Mahkamah Agung RI Tahun 2010, hlm. 40.

62 Menurut Sudikno Mertokusumo, suatu putusan hakim itu tidaklah berdiri sendiri, tetapi memiliki kekuatan berlaku untuk peristiwa serupa 


\section{Kesimpulan}

Artikel ini menyimpulkan, pertama, fotokopi surat yang tidak dapat dicocokkan dengan surat aslinya pertama-tama akan diterima secara formil di Pengadilan yaitu dengan dilakukan legalisasi oleh panitera pengadilan (fotokopi surat akan diterima secara formil dan dilakukan pemateraian (nazegeling)). Dalam persidangan, Majelis Hakim akan menilai fotokopi surat yang diajukan tersebut. Fotokopi surat dapat diterima sebagai alat bukti surat apabila bersesuaian atau dikuatkan dengan alat bukti lain, sebagaimana dimuat dalam yurisprudensi Putusan Mahkamah Agung Nomor 112 K/Pdt/1996 (diterima karena dapat dicocokkan dengan aslinya atau dikuatkan dengan alat bukti lain) dan Putusan Mahkamah Agung Nomor $410 \mathrm{~K} /$ pdt / 2004 (diterima karena diakui dan dibenarkan oleh pihak lawan). Yurisprudensi ini telah diikuti dalam perkara yang ditelaah dalam artikel ini. Dalam Putusan Pengadilan Negeri Jakarta Pusat Nomor 164/Pdt.G/2004/PN.Jkt.Pst jo. Putusan Pengadilan Tinggi Jakarta Nomor 234/Pdt/2005/PT.DKI jo. Putusan Mahkamah Agung Nomor 1498 K/Pdt / 2006, fotokopi surat yang tidak dapat dicocokkan dengan aslinya diterima karena dikuatkan dengan pengakuan pihak lawan. Sedangkan dalam Putusan Pengadilan Negeri Pontianak Nomor 52/Pdt.G/2003/PN.Ptk, fotokopi surat diterima sekalipun tidak dapat dicocokkan dengan aslinya dikarenakan dikuatkan dengan alat bukti keterangan saksi. Kedua, fotokopi surat (baik surat akta maupun bukan akta) yang tidak dapat dicocokkan dengan aslinya namun bersesuaian atau dikuatkan dengan alat bukti lain, memiliki kekuatan pembuktian yang bebas (penilaiannya diserahkan kepada hakim). Ia, fotokopi, tidak dapat berdiri sendiri, melainkan

yang terjadi kemudian. Hal ini dilakukan demi tercapainya kesatuan dan kepastian hukum. Kesatuan hukum menurut keseragaman putusan terhadap perkara yang sama atau serupa atau hampir sama, sedangkan kepastian hukum mengharapkan agar perkara yang serupa tidak diputus berbeda. Jadi putusan hakim memiliki sifat normatif, artinya putusan hakim tidak hanya berlaku bagi peristiwa tertentu saja, tetapi juga berlaku bagi peristiwa-peristiwa lainnya yang sama atau serupa yang terjadi kemudian. Mertokusumo, Mengenal Hukum: Suatu Pengantar (Yogyakarta: Liberty, cetakan ketiga, 2007), hlm. 114. 
harus dikaitkan dengan alat bukti lainnya yang sah. Hal ini perlu dalam upaya menjaga kepastian hukum yang sesuai dengan sistem pembuktian positif dalam hukum acara perdata.

\section{Daftar Pustaka}

\section{Artikel/Buku/Laporan}

Apriani, Erpinka. "Kepastian Hukum Sertipikat Hak Atas Tanah Kaitannya dengan Ketentuan Pasal 32 ayat (2) Peraturan Pemerintah Nomor 24 Tahun 1997 tentang Pendaftaran Tanah.” Tesis, Universitas Diponegoro, Semarang, 2007.

Boediarto, M. Ali. Kompilasi Kaidah Hukum Putusan Mahkamah Agung Hukum Acara Perdata: Masa Setengah Abad. Jakarta: Swara Justisia, 2005.

Butarbutar, Elisabeth Nurhaini. "Arti Pentingnya Pembuktian dalam Proses Penemuan Hukum di Peradilan Perdata”. Mimbar Hukum, 22, 2 (2010): 347-359. DOI: 10.22146/jmh.16225.

Hamzah, Andi. Pengantar Hukum Acara Pidana di Indonesia. Jakarta: Chalia Indonesia, 1984.

Harahap, M. Yahya. Hukum Acara Perdata Tentang Gugatan, Persidangan, Penyitaan, Pembuktian, dan Putusan Pengadilan. Jakarta: Sinar Grafika, 2004.

Https: / / kbbi.web.id/. Diakses 12/11/2019.

Makarao, Taufik. Pokok-Pokok Hukum Acara Perdata. Jakarta: Rineka Cipta, 2004.

Mertokusumo, Sudikno. Hukum Acara Perdata Indonesia. Yogyakarta: Liberty, edisi ketujuh, 2006.

Mertokusumo, Sudikno. Mengenal Hukum: Suatu Pengantar. Yogyakarta: Liberty, cetakan ketiga, 2007.

Nasir, Muhammad. Hukum Acara Perdata. Jakarta: Djambatan, cetakan kedua, 2005.

Ramelan, Soetomo. "Peranan Surat dalam Hukum Pembuktian". Jurnal Hukum dan Pembangunan, 17, 1 (1987): 6-11. DOI: 10.21143/ jhp.vol17.no1.1226.

Ratna, Winotia. "Perbandingan Alat Bukti Keterangan Saksi pada 
Hukum Acara Perdata dalam Sistem Hukum Indonesia dengan Singapura: Studi Kasus Beckket Pte. Ltd. Melawan Deutcshe Bank Ag.”. Skripsi, Universitas Indonesia, Depok, 2008.

RepublikIndonesia, Mahkamah Agung. YurisprudensiMahkamahAgung RI Tahun 2010. Jakarta: Badan Penelitian dan Pengembangan \& Pendidikan dan Pelatihan Hukum dan Peradilan, 2010.

Republik Indonesia, Pengadilan Tinggi Agama Makassar. Buku

Pedoman Kerja Hakim, Panitera dan Jurusita Sewilayah Pengadilan Tinggi Agama Makassar. Makassar: tanpa penerbit, edisi revisi, 2011.

Samosir, Djamanat. Hukum Acara Perdata: Tahap-Tahap Penyelesaian Perkara Perdata. Bandung: Nuansa Aulia, 2011.

Samudera, Teguh. Hukum Pembuktian dalan Acara Perdata. Bandung: PT. Alumni, cetakan kedua, 2004.

Soeroso, R. Hukum Acara Perdata Lengkap dan Praktis HIR, Rbg., dan Yurisprudensi. Jakarta: Sinar Grafika, cetakan kedua, 2011.

Subekti, R. Hukum Pembuktian. Jakarta: Pradnya Paramita, cetakan ketujuh belas, 2008.

Syahrani, Riduan. Hukum Acara Perdata di Lingkungan Peradilan Umum. Jakarta: Pustaka Karini, 1988.

\section{Peraturan Hukum}

Het Herziene Indonesisch Reglement (HIR atau Reglemen Indonesia yang diperbaharui: S. 1848 No. 16, S. 1941 No. 44).

Rechtsreglement Buitengewesten (Rbg. atau Reglemen daerah seberang: S. 1927 No. 227).

Republik Indonesia. Kitab Undang-Undang Hukum Perdata (Burgerlijk Wetboek). Diterjemahkan oleh R. Subekti dan R. Tjitrosudibio. Jakarta: Pradnya Paramita, 2004.

Republik Indonesia. Undang-Undang Nomor 30 Tahun 2004 tentang Jabatan Notaris. Lembaran Negara Tahun 2004 Nomor 117, Tambahan Lembaran Negara Nomor 4432. 